\title{
Platform for the rapid construction and evaluation of GPCRs for crystallography in Saccharomyces cerevisiae
}

\author{
Mitsunori Shiroishi ${ }^{1,2,3^{*}}$, Hirokazu Tsujimoto ${ }^{1,3}$, Hisayoshi Makyio ${ }^{1}$, Hidetsugu Asada ${ }^{1,3}$, Takami Yurugi-Kobayashi 1,3, \\ Tatsuro Shimamura ${ }^{1,3}$, Takeshi Murata ${ }^{1}$, Norimichi Nomura' ${ }^{1}$, Tatsuya Haga ${ }^{4}$, So Iwata ${ }^{1,3,5^{*}}$ and Takuya Kobayashi ${ }^{1,3,6^{*}}$
}

\begin{abstract}
Background: Recent successes in the determination of G-protein coupled receptor (GPCR) structures have relied on the ability of receptor variants to overcome difficulties in expression and purification. Therefore, the quick screening of functionally expressed stable receptor variants is vital.

Results: We developed a platform using Saccharomyces cerevisiae for the rapid construction and evaluation of functional GPCR variants for structural studies. This platform enables us to perform a screening cycle from construction to evaluation of variants within 6-7 days. We firstly confirmed the functional expression of 25 full-length class A GPCRs in this platform. Then, in order to improve the expression level and stability, we generated and evaluated the variants of the four GPCRs (hADRB2, hCHRM2, hHRH1 and hNTSR1). These stabilized receptor variants improved both functional activity and monodispersity. Finally, the expression level of the stabilized hHRH1 in Pichia pastoris was improved up to $65 \mathrm{pmol} / \mathrm{mg}$ from negligible expression of the functional full-length receptor in S. cerevisiae at first screening. The stabilized hHRH1 was able to be purified for use in crystallization trials.
\end{abstract}

Conclusions: We demonstrated that the S. cerevisiae system should serve as an easy-to-handle and rapid platform for the construction and evaluation of GPCR variants. This platform can be a powerful prescreening method to identify a suitable GPCR variant for crystallography.

Keywords: G-protein coupled receptor, Membrane protein, High expression, Screening, Receptor variants, Structural study, Saccharomyces cerevisiae

\section{Background}

G-proteincoupled receptors (GPCRs), which represent the largest family of integral membrane proteins, play pivotal roles in mediating signal transduction events in response to ligands such as peptides and amines. GPCRs are major therapeutic drug targets and represent $~ 30 \%$ of the market share of all prescription drugs [1]. Although the high-resolution 3D structures of the target GPCRs provide good initial models for drug design, difficulties in expression and purification have been a major

\footnotetext{
*Correspondence: shiroish@phar.kyushu-u.ac.jp; s.iwata@mfour.med.kyoto-u. ac.jp; t-coba@mfour.med.kyoto-u.ac.jp

'Iwata Human Receptor Crystallography project, ERATO, JST,

Yoshidakonoe-choSakyo-ku, Kyoto 606-8501, Japan

${ }^{2}$ Graduate School of Pharmaceutical Sciences, Kyushu University, 3-1-1

Maidashi, Higashi-ku, Fukuoka 812-8582, Japan

Full list of author information is available at the end of the article
}

bottleneck for structural study. Large quantities of highquality pure protein are generally required for X-ray crystallography. With the exception of rhodopsin [2-4], which is naturally abundant and can be isolated from rod outer membranes in the eyes, GPCRs generally are not sufficiently abundant to be isolated from their endogenous tissues. Therefore, overexpression in a heterologous host is needed. Various types of hosts have been evaluated for use in GPCR expression, including bacteria, yeast, insect, and mammalian cells, as well as cellfree systems [5, 6]. However, only a limited number of GPCRs have been successfully expressed and purified on a large scale. One reason for that may be their instability, which is most likely due to their dynamic activity in the membrane. Recent successes in structure determination have demonstrated the importance of stabilizing

\section{Biomed Central}


receptor in order to achieve high expression and/or facilitation of crystallization [7-13].

Because it is almost impossible to predict what modifications will improve the expression and/or stability of receptors, suitable variants must be selected from the pool of possible variants by trial and error. To facilitate structural studies of GPCRs, a screening system is required that will enable rapid selection of variants. Insect cells have been used as a successful host for structural study, but the screening is laborious and time consuming. E. coli has recently been used to screen the thermally stable GPCR variants of turkey $\beta 1$ adrenergic receptor (tADRB1) [14], human adenosine A2a receptor (hADORA2A) [15, 16], and rat neurotensin receptor 1 (rNTSR1) [17]. In addition the crystal structures of the stabilized variants were determined for tADRB1 and hADORA2A [18, 19]. However, only a limited number of functionally expressed receptors have been successfully generated in E. coli [20].

Yeast is a more preferred host for the expression of GPCRs than E. coli. Yeast has a protein quality control system similar to that of mammalian cells, which enables numerous posttranslational modifications and correct disulfide formation of mammalian membrane proteins. This similarity may lead to more functional expression of GPCRs in yeast [21]. S. cerevisiae in particular is stable for protein expression, easy to manipulate, and quick to proliferate. S. cerevisiae has been extensively tailored for the screening of functional GPCR mutants [22]. In addition, many GPCRs can be as highly expressed in yeast as in mammalian cells [21, 23].

We previously established a GFP-based pipeline for the expression and purification of non-GPCR membrane proteins in S. cerevisiae [24, 25]. S. cerevisiae permits the rapid cloning of genes of interest into the $2-\mu$ plasmid by homologous recombination, enabling the direct expression and evaluation of the proteins. The amount and integrity of the target membrane protein can be estimated from the whole-cell fluorescence and in-gel fluorescence after SDS-polyacrylamide gel electrophoresis (SDS-PAGE). Monodispersity, which is a good indicator for purification, can be observed by fluorescencedetection size exclusion chromatography (FSEC) [26]. The gene of a target protein can be transformed with the divided PCR fragments in one step [27]. In the present study, we demonstrate that the platform using $S$. cerevisiae is very useful for the rapid construction and evaluation of GPCR variants for structural study. The stabilized GPCRs in S. cerevisiae were expressed at higher levels in P. pastoris yeast. Finally, the stabilized human histamine $\mathrm{H} 1$ receptor was successfully purified for structural biology study.

\section{Results}

GFP-based platform for the rapid construction and evaluation of GPCR variants in S. cerevisiae

The GFP-based platform using $S$. cerevisiae for the construction and evaluation of GPCR variants is illustrated in Figure 1. The GPCR variants were designed and the genes were generated as PCR fragments (Figure 1A). The 2- $\mu$ plasmid named pDDGFP-2, which has a GAL1 promoter, and $S$. cerevisiae strain FGY217 were used [24] (Figure 1B). This plasmid/strain combination resulted in the best expression of membrane proteins. The genes of interest were integrated into the plasmid by homologous recombination in S. cerevisiae in one step via introduction of a mixture of linearized plasmid and PCR products. The clone harboring the GPCR variant is selected on an agar plate without uracil (Ura-). After small-scale $(10 \mathrm{~mL})$ culturing, the functional expressions are evaluated by radioligand-binding assays. The monodispersity of the detergent-solubilized receptor is assessed by FSEC by detecting the C-terminal GFP, which enables the evaluation without purification. In the present study, the SEC eluate was collected in a 96-well microplate and the fluorescence was detected by a plate reader following the existing protocol [24, 25]. Therefore, a relatively large amount of samples $(2 \sim 3 \mathrm{mg}$ of total membrane protein) was needed, and the membranes were prepared from an intermediate-scale (200 mL) culture. We have confirmed that a similar result could be obtained from a small-scale $(10 \mathrm{~mL})$ culture by using a fluorescence detector at the outlet of the SEC column (data not shown). By omitting the intermediate-scale culturing, this platform enables us to perform a screening cycle within 6-7 days, compared to 16-18 days in $P$. pastoris or 30-35 days in insect cells using baculovirus (Figure $1 \mathrm{C}$ ).

\section{Overexpression of full-length GPCRs in S. cerevisiae}

First, 25 full-length GPCRs were expressed and evaluated using this platform. The integrity of the GPCR-GFP fusions examined by in-gel fluorescence after standard SDS-PAGE [28] indicated that most of the GPCRs were not degraded and appeared as a single major band in the gel (Additional file 1: Figure S1). Table 1 shows the expression levels of full-length receptors estimated by the GFP fluorescence (total expression) and single-point radioligand-binding assay (functional expression). Without any signal sequence and under standard culture conditions (no additives and at $30{ }^{\circ} \mathrm{C}$ ), the ligand-binding activities of 12 GPCRs were zero or lower than $0.1 \mathrm{pmol} /$ mg. The N-terminal yeast alpha mating factor signal sequence which improved the ligand-binding activities of GPCRs [29-32]. In the previous report on GPCR expression in $P$. pastoris, supplementation of dimethyl sulfoxide (DMSO) and lowering induction temperature to $20{ }^{\circ} \mathrm{C}$ 

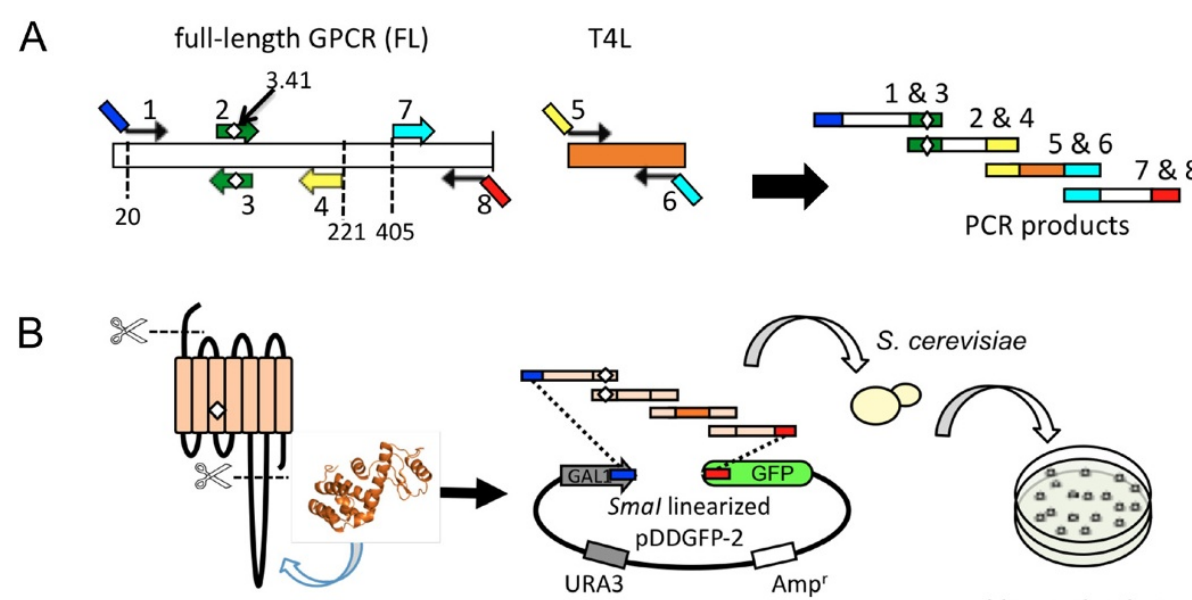

Construction design

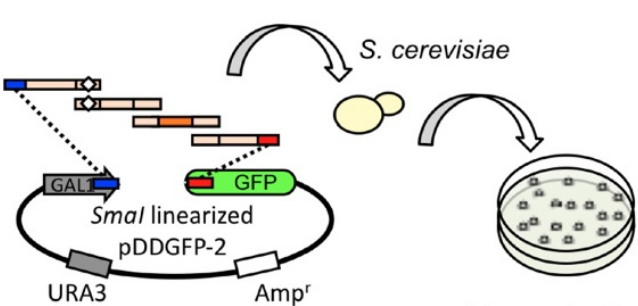

PCR and transformation

Ura- selection

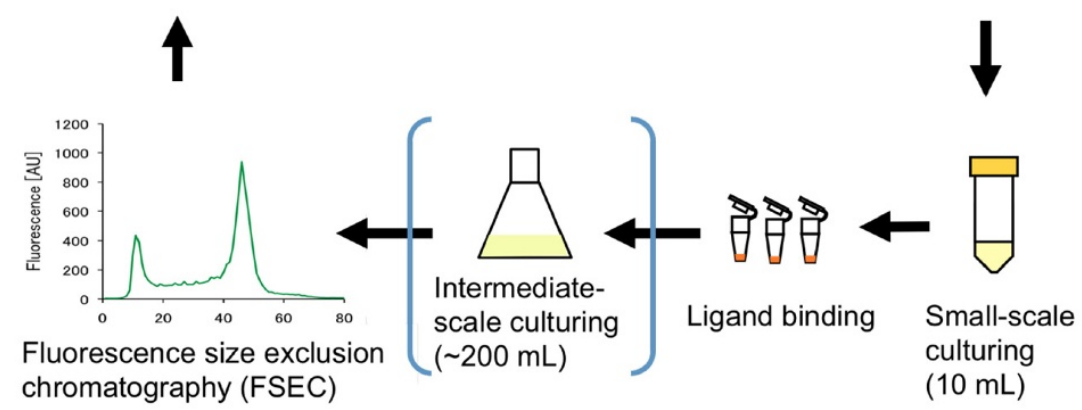

C

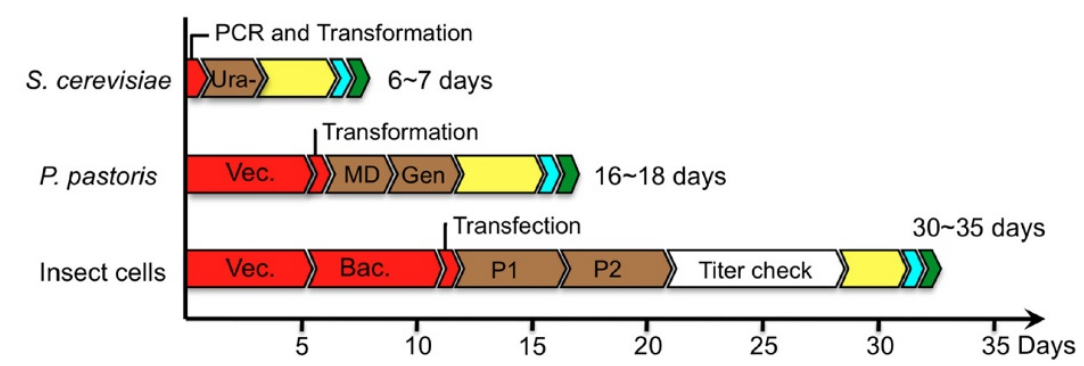

Figure 1 Overview of the construction and evaluation platform of GPCR variants in S. cerevisiae. (A) Primer design of a variant. As an example, the $\mathrm{hHRH} 1$ variant with truncation of the N-terminal region, a mutation at the 3.41 position in TM3 and T4L fusion to the i3-loop is shown. The four PCR fragments are generated using the indicated primer pairs from full-length GPCR and T4L (Additional file 1: Table S1). The same colored overlapping regions were necessary for homologous recombination in S. cerevisiae. (B) Illustration of a cycle from construction design to evaluation for the GPCR variants. (C) Flow and time-scale of the construction and evaluation of GPCR variants in three hosts. Schemes for small-scale culturing are shown in yellow and orange, respectively. Evaluations by ligand-binding assays and FSEC are shown in cyan and green, respectively. Vec:: preparation of expression vector, Bac:: preparation of Bacmid, Ura-: selection on a Ura- plate, MD: selection on a minimum dextrose (MD) plate, Gen: selection on a geneticine plate, P1 and P2: P1 and P2 virus preparation, respectively.

increased the ligand-binding activity of receptor [33]. Then four culture conditions were examined: the presence or absence of $2.5 \%$ DMSO and two induction temperatures $\left(20{ }^{\circ} \mathrm{C}, 30{ }^{\circ} \mathrm{C}\right)$. The functional expression of 24 of 25 GPCRs was increased in S. cerevisiae in the optimized conditions. For many receptors, there was little correlation between the intensity of GFP fluorescence and ligand-binding activity, suggesting that the intensity of GFP fluorescence itself is not a good indicator of functional expression in this platform. After these optimizations, 25 GPCRs were functionally expressed. However, the expression level remained insufficient for structural study.

Use of S. cerevisiae as a platform for the construction and evaluation of GPCR variants

We generated and evaluated the variants of the three GPCRs shown in Table 2 (hCHRM2, hHRH1, hNTSR1) using the GFP-based platform in S. cerevisiae. In addition, 
Table 1 Summary of the expression level and functional activity of the 25 GPCRs expressed in S. cerevisiae under different culture conditions in small-scale cultures

\begin{tabular}{|c|c|c|c|c|c|c|c|c|c|c|}
\hline & & \multirow{3}{*}{$\frac{\text { Temp }}{\text { DMSO }}$} & \multicolumn{4}{|c|}{$\underline{a-f a c t o r}(-)$} & \multicolumn{4}{|c|}{ a-factor $(+)$} \\
\hline & & & \multicolumn{2}{|c|}{$30^{\circ} \mathrm{C}$} & \multicolumn{2}{|c|}{$20^{\circ} \mathrm{C}$} & \multicolumn{2}{|c|}{$30^{\circ} \mathrm{C}$} & \multicolumn{2}{|l|}{$20^{\circ} \mathrm{C}$} \\
\hline & & & - & + & - & + & - & + & - & + \\
\hline \multirow[t]{2}{*}{ Acetylcholine receptor } & hCHRM2 & $\mathrm{TE}(\mathrm{mg} / \mathrm{L})$ & 1.5 & 1.5 & 1.7 & 1.6 & 0.53 & 0.78 & 0.62 & 0.56 \\
\hline & & $\mathrm{FE}(\mathrm{pmol} / \mathrm{mg})$ & 0.03 & 0.12 & 0.05 & 0.21 & 0.08 & 0.28 & 0.30 & 0.66 \\
\hline \multirow[t]{2}{*}{ Adenosine receptor } & hADORA2A & $\mathrm{TE}(\mathrm{mg} / \mathrm{L})$ & 0.20 & 0.17 & 0.06 & 0.06 & 0.70 & 0.68 & 0.84 & 0.92 \\
\hline & & $\mathrm{FE}(\mathrm{pmol} / \mathrm{mg})$ & 5.3 & 6.8 & 2.4 & 2.4 & 24 & 25 & 16 & 20 \\
\hline \multirow[t]{2}{*}{ Adrenergic receptor } & hADRB2 & $\mathrm{TE}(\mathrm{mg} / \mathrm{L})$ & 1.5 & 1.6 & 0.76 & 0.93 & 0.81 & 1.0 & 0.91 & 0.71 \\
\hline & & $\mathrm{FE}(\mathrm{pmol} / \mathrm{mg})$ & 0.06 & 0.07 & 0.10 & 0.18 & 0.36 & 0.40 & 0.52 & 1.1 \\
\hline \multirow[t]{6}{*}{ Dopamine receptor } & hDRD1 & $\mathrm{TE}(\mathrm{mg} / \mathrm{L})$ & 0.53 & 0.81 & 0.75 & 0.9 & 0.44 & 0.62 & 0.54 & 0.57 \\
\hline & & $\mathrm{FE}(\mathrm{pmol} / \mathrm{mg})$ & 0.07 & 0.02 & 0.05 & 0.01 & 0.01 & 0.03 & 0.01 & 0.04 \\
\hline & hDRD2 & $\mathrm{TE}(\mathrm{mg} / \mathrm{L})$ & 0.21 & 0.12 & 0.26 & 0.24 & 0.21 & 0.32 & 0.34 & 0.31 \\
\hline & & $\mathrm{FE}(\mathrm{pmol} / \mathrm{mg})$ & 0.37 & 0.58 & 0.72 & 1.57 & 0.35 & 1.09 & 1.6 & 3.2 \\
\hline & hDRD4 & $\mathrm{TE}(\mathrm{mg} / \mathrm{L})$ & 2.0 & 2.5 & 1.1 & 1.3 & 0.78 & 0.79 & 0.8 & 1.3 \\
\hline & & $\mathrm{FE}(\mathrm{pmol} / \mathrm{mg})$ & 0.21 & 0.25 & 0.19 & 0.3 & 0.22 & 0.34 & 0.17 & 0.17 \\
\hline \multirow[t]{6}{*}{ Histamine receptor } & hHRH1 & TE (mg/L) & 0.95 & 1.1 & 1.6 & 1.7 & 0.37 & 0.53 & 0.65 & 0.63 \\
\hline & & $\mathrm{FE}(\mathrm{pmol} / \mathrm{mg})$ & 0 & 0 & 0.34 & 0.61 & 0 & 0.15 & 0 & 0 \\
\hline & $\mathrm{hHRH3}$ & $\mathrm{TE}(\mathrm{mg} / \mathrm{L})$ & 0.96 & 1.0 & 0.61 & 0.55 & 0.48 & 0.64 & 0.61 & 0.81 \\
\hline & & $\mathrm{FE}(\mathrm{pmol} / \mathrm{mg})$ & 0.4 & 0.62 & 0.24 & 0.11 & 0.74 & 0.87 & 0.27 & 0.32 \\
\hline & $\mathrm{hHRH} 4$ & $\mathrm{TE}(\mathrm{mg} / \mathrm{L})$ & 0.38 & 0.51 & 0.67 & 0.75 & 0.33 & 0.55 & 0.42 & 0.52 \\
\hline & & $\mathrm{FE}(\mathrm{pmol} / \mathrm{mg})$ & 0.45 & 0.6 & 0.16 & 0.27 & 0.68 & 1.1 & 0.22 & 0.15 \\
\hline \multirow[t]{8}{*}{ Neuropeptide Y } & hNPY1R & $\mathrm{TE}(\mathrm{mg} / \mathrm{L})$ & 0.11 & 0.11 & 0.11 & 0.11 & 0.36 & 0.4 & 0.25 & 0.26 \\
\hline & & $\mathrm{FE}(\mathrm{pmol} / \mathrm{mg})$ & 0 & 0 & 0 & 0 & 0 & 0.12 & 0.07 & 0.21 \\
\hline & hNPYR2 & TE (mg/L) & 0.51 & 0.54 & 0.24 & 0.23 & 0.18 & 0.22 & 0.2 & 0.19 \\
\hline & & $\mathrm{FE}(\mathrm{pmol} / \mathrm{mg})$ & 0 & 0.14 & 0.05 & 0 & 0 & 0 & 0.03 & 0 \\
\hline & hNPYR4 & $\mathrm{TE}(\mathrm{mg} / \mathrm{L})$ & 1.0 & 1.5 & 0.91 & 1.2 & 0.27 & 0.61 & 0.24 & 0.27 \\
\hline & & $\mathrm{FE}(\mathrm{pmol} / \mathrm{mg})$ & 0.13 & 0.18 & 0.1 & 0.07 & 0.21 & 0.35 & 0 & 0 \\
\hline & hNPYR5 & $\mathrm{TE}(\mathrm{mg} / \mathrm{L})$ & 0.31 & 0.46 & 0.82 & 0.89 & 0.34 & 0.51 & 0.52 & 0.61 \\
\hline & & $\mathrm{FE}(\mathrm{pmol} / \mathrm{mg})$ & 0.04 & 0.02 & 0.07 & 0.13 & 0 & 0.01 & 0 & 0 \\
\hline \multirow[t]{4}{*}{ Neurotensin receptor } & hNTSR1 & TE (mg/L) & 0.59 & 1.0 & 0.87 & 0.93 & 0.52 & 0.8 & 0.83 & 1.1 \\
\hline & & $\mathrm{FE}(\mathrm{pmol} / \mathrm{mg})$ & 0.15 & 0.15 & 0.15 & 0.15 & 0.32 & 0.43 & 0.3 & 0.78 \\
\hline & hNTSR2 & $\mathrm{TE}(\mathrm{mg} / \mathrm{L})$ & 0.73 & 1.3 & 1.4 & 1.5 & 0.65 & 1.0 & 0.8 & 0.89 \\
\hline & & $\mathrm{FE}(\mathrm{pmol} / \mathrm{mg})$ & 0.18 & 0.21 & 0.26 & 0.18 & 0.19 & 0.19 & 0.11 & 0.16 \\
\hline \multirow[t]{2}{*}{ Opioid receptor } & hOPRK1 & $\mathrm{TE}(\mathrm{mg} / \mathrm{L})$ & 0.54 & 0.76 & 0.4 & 0.34 & 0.24 & 0.32 & 0.27 & 0.29 \\
\hline & & $\mathrm{FE}(\mathrm{pmol} / \mathrm{mg})$ & 0 & 0.08 & 0.09 & 0.16 & 0 & 0.11 & 0.1 & 0.15 \\
\hline \multirow[t]{6}{*}{ Prostanoid receptor } & hPTGER2 & $\mathrm{TE}(\mathrm{mg} / \mathrm{L})$ & 0.24 & 0.16 & 0.2 & 0.18 & 0.28 & 0.43 & 0.49 & 0.48 \\
\hline & & $\mathrm{FE}(\mathrm{pmol} / \mathrm{mg})$ & 0 & 0 & 0.19 & 0 & 0 & 0.18 & 0.1 & 0.47 \\
\hline & hPTGER4 & TE (mg/L) & 0.11 & 0.15 & 0.09 & 0.11 & 1.4 & 1.7 & 1.5 & 1.4 \\
\hline & & $\mathrm{FE}(\mathrm{pmol} / \mathrm{mg})$ & 0 & 0 & 0 & 0 & 0 & 0 & 0.4 & 0 \\
\hline & hTBXA2R & $\mathrm{TE}(\mathrm{mg} / \mathrm{L})$ & 0.52 & 0.63 & 0.26 & 0.26 & 0.21 & 0.21 & 0.34 & 0.32 \\
\hline & & $\mathrm{FE}(\mathrm{pmol} / \mathrm{mg})$ & 0.15 & 0.23 & 0.05 & 0.02 & 0.03 & 0 & 0.78 & 0.7 \\
\hline \multirow[t]{3}{*}{ Serotonin receptor } & hHTR1B & $\mathrm{TE}(\mathrm{mg} / \mathrm{L})$ & 0.9 & 1.1 & 0.46 & 0.58 & 0.34 & 0.23 & 0.46 & 0.46 \\
\hline & & $\mathrm{FE}(\mathrm{pmol} / \mathrm{mg})$ & 0.54 & 0.62 & 0.71 & 0.48 & 0.89 & 1.1 & 2.0 & 1.9 \\
\hline & hHTR1D & TE (mg/L) & 0.34 & 0.53 & 0.67 & 0.76 & 0.29 & 0.3 & 0.33 & 0.22 \\
\hline
\end{tabular}


Table 1 Summary of the expression level and functional activity of the 25 GPCRs expressed in S. cerevisiae under different culture conditions in small-scale cultures (Continued)

\begin{tabular}{|c|c|c|c|c|c|c|c|c|c|c|}
\hline & & $\mathrm{FE}(\mathrm{pmol} / \mathrm{mg})$ & 0.06 & 0.03 & 0.33 & 0.46 & 0.46 & 0.52 & 1.7 & 1.6 \\
\hline & hHTR5A & TE (mg/L) & 0.3 & 0.62 & 0.48 & 0.59 & 0.2 & 0.25 & 0.23 & 0.23 \\
\hline & & $\mathrm{FE}(\mathrm{pmol} / \mathrm{mg})$ & 0.02 & 0.18 & 0 & 0.07 & 0.24 & 0.34 & 0 & 0 \\
\hline \multirow[t]{6}{*}{ Tachykinin receptor } & hTACR1 & $\mathrm{TE}(\mathrm{mg} / \mathrm{L})$ & 1.1 & 1.7 & 1.1 & 1.1 & 0.67 & 0.83 & 0.65 & 0.57 \\
\hline & & $\mathrm{FE}(\mathrm{pmol} / \mathrm{mg})$ & 0 & 0.45 & 0.14 & 0.02 & 0.60 & 0.59 & 0.09 & 0.15 \\
\hline & hTACR2 & TE (mg/L) & 1.4 & 1.7 & 2.5 & 2.2 & 0.46 & 0.71 & 0.96 & 0.86 \\
\hline & & $\mathrm{FE}(\mathrm{pmol} / \mathrm{mg})$ & 0.40 & 0.85 & 1.1 & 2.9 & 0.75 & 0.65 & 1.3 & 3.8 \\
\hline & rTACR2 & $\mathrm{TE}(\mathrm{mg} / \mathrm{L})$ & 0.11 & 0.10 & 0.06 & 0.04 & 0.56 & 0.86 & 1.0 & 1.1 \\
\hline & & FE (pmol/mg) & 0.25 & 0.2 & 0.08 & 0.06 & 1.3 & 1.9 & 5.2 & 7.4 \\
\hline
\end{tabular}

"TE" represents the total expression level estimated from whole-cell GFP fluorescence (mg/L culture). The intensity of $200 \mu \mathrm{L}$ of $1 \mu \mathrm{M}$ purified yEGFP in the $96-\mathrm{well}$ plate was 7500 [rfu]. Whole-cell fluorescence was measured in a $200-\mu \mathrm{L}$ cell suspension by using cultures at the same cell density as the culture. Therefore, the expression level was calculated from: TE $[\mathrm{mg} / \mathrm{L}]=($ GFP counts of whole cell $[\mathrm{rfu}]) /\left(7500^{*} 10^{6}[\mathrm{rfu} * \mathrm{~L} / \mathrm{mol}]\right)^{*}\left(\mathrm{molecular}\right.$ weight $\left.{ }^{*} 10^{3}[\mathrm{mg} / \mathrm{mol}]\right)$. "FE" represents the functional activity from a single-point radioligand binding assay (pmol/mg membrane protein). Conditions highlighted in bold type are the best and second-best conditions for the GFP-based expression level and the functional activity.

the hADRB2 variant (E122W-N187E-Cd), whose structure has been solved as a T4L-fusion [34], was also generated. To construct GPCR variants, the following four variant modules were considered: (1) A truncation of flexible long $\mathrm{N}$ - $(\mathrm{Nd})$ or C-terminal residues $(\mathrm{Cd})$, which effectively increases GPCR expression in some reported cases (e.g., ref. [35]). (2) A point mutation at the 3.41 position in transmembrane helix 3 (Additional file 1: Figure S2A). The

Table 2 GPCR variants constructed and evaluated in S. cerevisiae in this study

\begin{tabular}{lll}
\hline GPCR & Variant name & Deletions and mutations \\
\hline hADRB2 & FL & full-length ADRB2 (1-413) \\
& ADRB2mut & ADRB2(1-365), E122W, N187E \\
hCHRM2 & FL & full-length CHRM2 (1-466) \\
& Nd-i3d & CHRM2 (11-466), i3d(233-380) \\
& Nd-M112W-i3d & CHRM2 (11-466), M112W, i3d(233-380) \\
hHRH1 & FL & full-length HRH1 (1-487) \\
& Nd-i3d & HRH1 (20-487), i3d (229-397) \\
& Nd-T4L & HRH1 (20-487), T4L \\
& Nd-F116W-i3d & HRH1 (20-487), F116W, i3d (229-397) \\
& Nd-F116W-T4L & HRH1 (20-487), F116W, T4L \\
hNTSR1 & FL & full-length NTSR1 (1-418) \\
& Nd-Cd & NTSR1 (43-385) \\
& Nd-T4L-Cd & NTSR1 (43-385), T4L \\
& Nd-L157W-Cd & NTSR1 (43-385), L157W \\
& Nd-L157W-T4L-Cd & NTSR1 (43-385), L157W, T4L \\
& &
\end{tabular}

NTSR1 (43-385) means that the N- and C-terminal residues are truncated, the receptor starts from residue 43, and the receptor ends with residue 385 . E122W, M112W, F116W and L157W are the mutations to tryptophan at position 3.41. Deletion of the i3-loop from position 229 to 297 is indicated as i3d (229-297). T4L indicates the fusion of the T4 lysozyme sequence between TM5 and TM6. numbering is based on the general indexed position in the Ballesteros-Weinstein system [36]. Mutations at this position reportedly increase the thermal stability of hADRB2 [37]. (3) A deletion mutant of a long third intracellular loop (i3-loop) (abbreviated as i3d; Additional file 1: Figure S2B). A long i3-loop potentially becomes a target of degradation or receptor destabilization on the host cell surface. For muscarinic receptors, deletion of the i3-loop results in higher functional expression [38, 39]. (4) Replacement of part of the i3-loop by T4 lysozyme (T4L, residues from 2 to 161) (Additional file 1: Figure S2B); this replacement has been successful in crystallization and structural determination of hADRB2, hADORA2A, hDRD3 and hCXCR4 in cubic phase crystals [8, 11-13].

After small-scale culturing, the total receptor expressions and functional expressions were determined by GFP fluorescence and radioligand-binding assay, respectively (Additional file 1: Figure S3). These results showed that the intensity of GFP fluorescence itself is not a good indicator of functional expression. The ligand binding activity and monodispersity of the detergent-solubilized receptor of the variants that portrayed improved functional expression are shown in Figure 2. The hADRB2 variant Cd-E122W-N187E showed a 10-fold increase in ligand-binding activity. The hCHRM2 variant $\mathrm{Nd}-\mathrm{i} 3 \mathrm{~d}$ showed a 2.5 -fold increase. The hHRH1 variants $\mathrm{Nd}$-i3d and Nd-T4L displayed 7- and 26-fold increased activity, respectively. In hNTSR1, mutagenesis at the 3.41-position (Nd-L157W-Cd and Nd-L157W-T4L-Cd) increased activity by 1.5 -fold. Importantly, the variants that showed improved activity also exhibited improved FSEC profiles after solubilization with the mixed micelle of n-Dodecyl$\beta$-D-maltopyranoside (DDM) and cholesteryl hemisuccinate (CHS), which is commonly used for purification of GPCRs. This indicates that there is a correlation between 


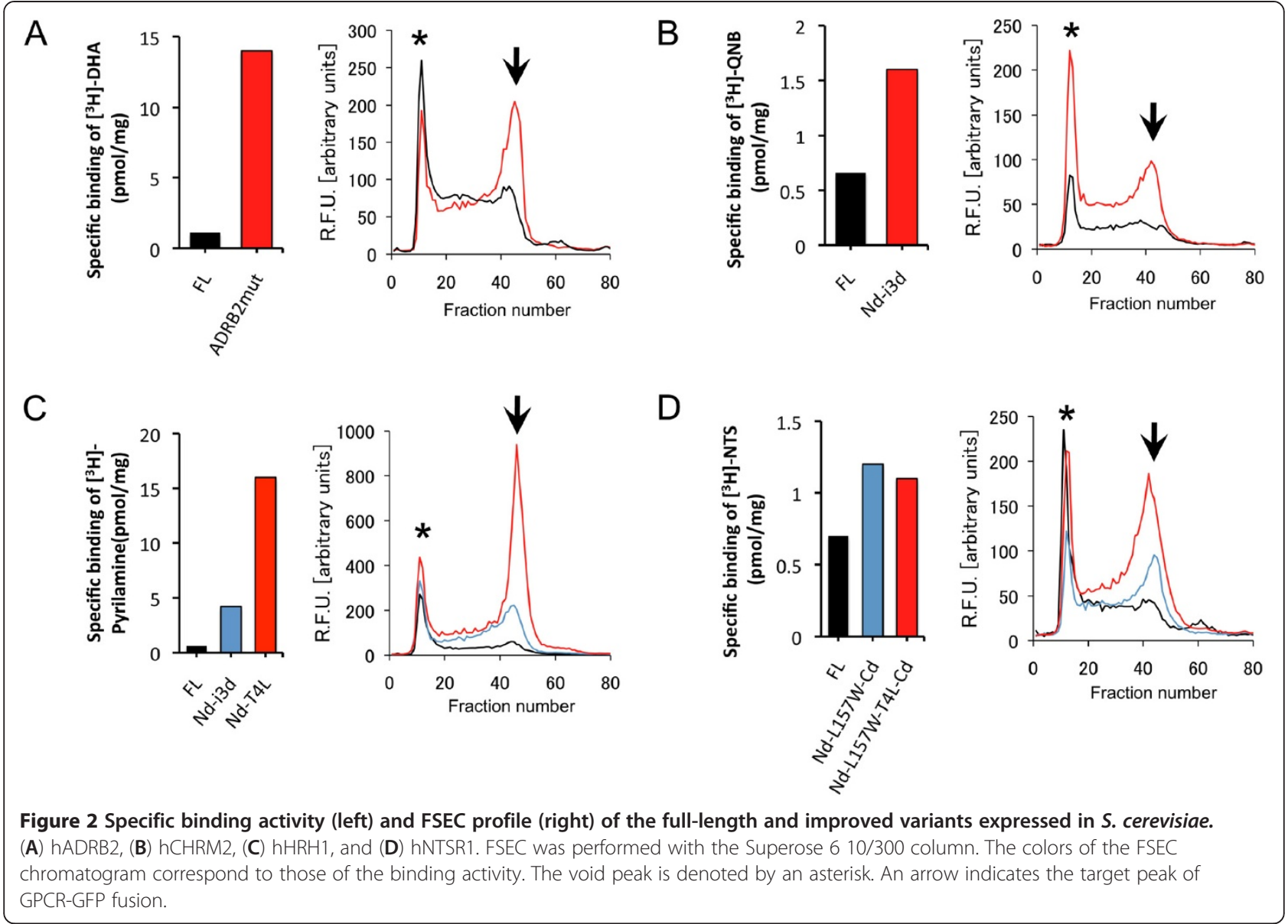

the improvement in both ligand-binding activity and monodispersity in GPCR variants.

\section{Expression of the GPCR variants in other hosts}

Human HRH1-Nd-T4L variant showed a high expression $(16 \mathrm{pmol} / \mathrm{mg})$ and good FSEC profile in $S$. cerevisiae. However, the expression of the other GPCR variants remained too low for purification. If the improved variants could be expressed in another host at higher levels, purification would be facilitated. While insect cells are currently known as the most successful host for GPCR expression for structural study, our recent successes in the structural determination of hHRH1 and human adenosine A2a receptor (hADORA2a) were achieved by using $P$. pastoris as a host cell [40, 41]. $P$. pastoris is easier to handle compared to insect cells, and can generate milligram quantities of high-quality mammalian GPCR protein as well as insect cells [42-46]. Therefore, we attempted to express selected GPCR variants in P. pastoris.

Improvements of ligand-binding activity and FSEC profiles of GPCR variants were also observed in $P$. pastoris (Figure 3). The hADRB2 variant E122W-N187E-Cd exhibited a large improvement in ligand-binding activity (80-fold) and a larger peak derived from monodisperse receptor in $P$. pastoris. In the hCHRM2 variant $\mathrm{Nd}-\mathrm{i} 3 \mathrm{~d}$, improvements in both ligand-binding activity (2-fold) and monodispersity were observed. For hHRH1, substantial improvements in ligand-binding activity and monodispersity in FSEC were observed for both $\mathrm{Nd}-\mathrm{i} 3 \mathrm{~d}$ and Nd-T4L (by 6- and 4-fold, respectively). Although the improvements in ligand-binding activity of the hNTSR1 variants Nd-157W-Cd and Nd-157W-T4L-Cd were only $\sim 1.5$-fold in $S$. cerevisiae, ligand-binding activity and monodispersity were largely improved in P. pastoris. We confirmed that improvements of GPCR variants were also observed in Sf9 insect cells (Additional file 1: Figure S4). For the receptors in the present study, the expression level in P. pastoris was the same or higher than that in insect cells.

\section{Purification of the GPCR variants}

The variants, hHRH1-Nd-i3d expressed in P. pastoris and hHRH1-Nd-T4L expressed in S. cerevisiae, were successfully purified in milligram quantities from a large-scale culture. The yield of functional expression estimated from 

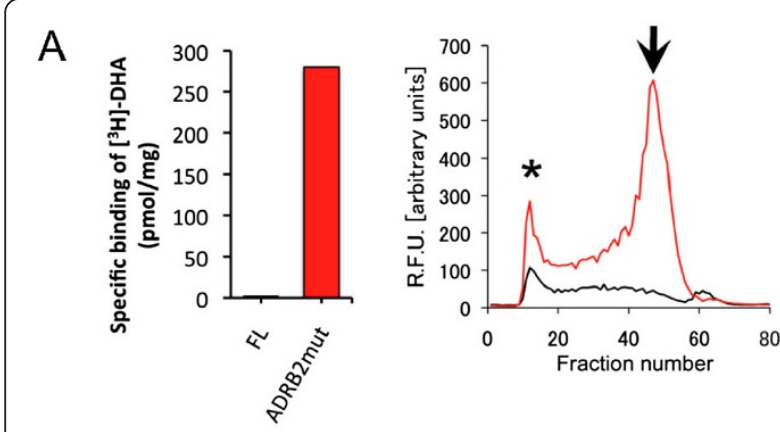

B
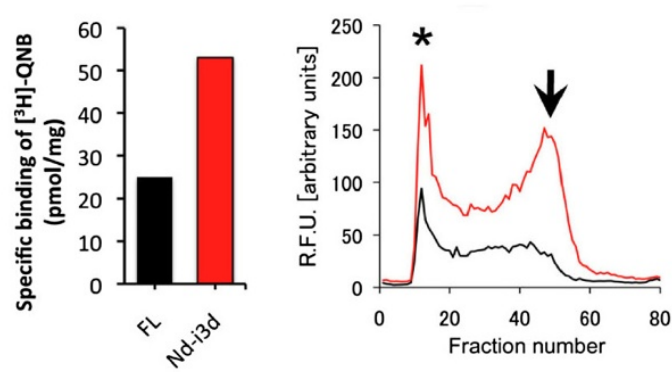

C
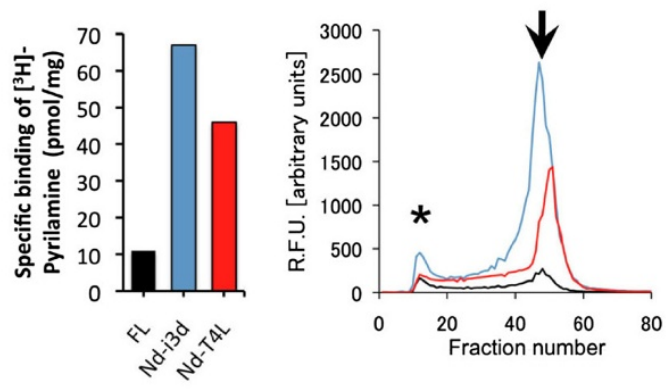

D
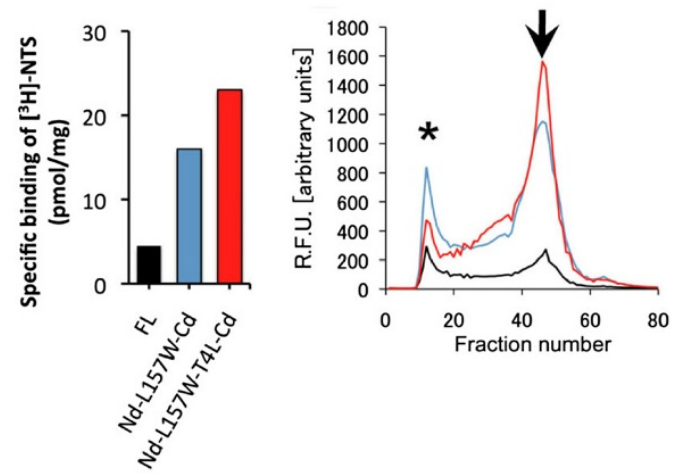

Figure 3 Evaluation of the GPCR variants expressed in $P$.

pastoris. The specific binding activities (left) and FSEC profiles (right) of full-length GPCRs and the improved GPCR variants expressed in P. pastoris are shown. The colors of the chromatogram correspond to those in the binding assays. (A) hADRB2, (B) hCHRM2, (C) hHRH1, (D) hNTSR1. FSEC was performed with a Superose 6 10/300 column. The void peak is denoted by an asterisk. The arrow indicates the target peak of GPCR fused to GFP. ligand binding assay were more than $0.3 \mathrm{mg}$ per $1 \mathrm{~L}$ culture for hHRH1-Nd-i3d expressed in P. pastoris and more than $0.04 \mathrm{mg}$ for hHRH1-Nd-T4L expressed in S. cerevisiae. The yield estimated from whole-cell GFP fluorescence intensities were $\sim 5 \mathrm{mg}$ for hHRH1-Nd-i3d expressed in P. pastoris and $\sim 1.2 \mathrm{mg}$ for hHRH1-Nd-T4L expressed in $S$. cerevisiae. The final yield after purification of hHRH1-Ndi3d expressed in P. pastoris, hHRH1-Nd-T4L expressed in S. cerevisiae were $0.3 \sim 0.4 \mathrm{mg}$ and $0.04 \mathrm{mg}$ per $1 \mathrm{~L}$ culture, respectively. These purified GPCR variants showed 90 95\% purity judging from SDS-PAGE and showed a high degree of monodispersity judging from size exclusion chromatography (SEC) with absorbance detection at $280 \mathrm{~nm}$ (Figure 4). The SEC profile of purified hHRH1-NdT4L expressed in P. pastoris was also monodisperse as described in our recent report [47].

\section{Discussion}

Approximately 800 GPCRs have been identified in the human genome. More than 40 receptors are now targeted by drugs, and more than 300 receptors could potentially be future drug targets [48, 49]. For a better understanding of ligand recognition and drug design, three-dimensional structures will be needed for each receptor. However, at present, only a handful of GPCR structures have been determined. One major bottleneck that hampers structural study is clearly the expression and purification of functional receptors. As shown in this study and many previous reports on GPCR expression, the expression level and/or stability of wild-type receptors are not sufficient. Therefore, for successful structural study, it is necessary to stabilize the receptors for high-level expression and crystallization. We demonstrated that a platform using S. cerevisiae enabled the rapid construction and selection of stabilized GPCR variants.

In this study, we presented examples of receptors that improved ligand-binding activity and monodispersity through the introduction of variant modules. If the initial variant module does not work well, optimizations might be needed to achieve a higher expression, such as changes in the length of the $\mathrm{N}$ - or C-terminal truncation and positions of the i3-loop deletion and/or the insertion of T4 lysozyme. Thermal stabilization will be required for the intrinsically unstable receptors, or for receptors that need to be crystallized in a smaller detergent. Thermal stabilizations have been achieved by mutagenesis to tryptophan at position 3.41 in TM3, alanine scanning mutagenesis, or random mutagenesis $[14,15,17,37,50]$. This platform using $S$. cerevisiae should facilitate such extensive construction screening much more easily and rapidly than in insect cells or mammalian cells. Our results suggest that there is a correlation between the ligand-binding activity and monodispersity; that is, a 

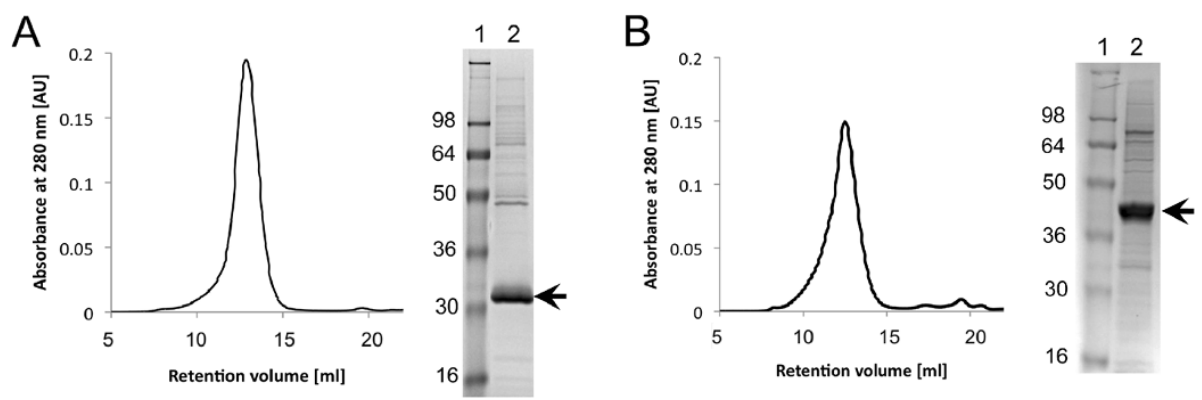

Figure 4 Purification of the receptor variant. (A) hHRH1-Nd-i3d expressed in P. pastoris, and (B) hHRH1-Nd-T4L expressed in S. cerevisiae. The size-exclusion chromatogram using Superdex 200 10/300 is shown in the left panel, and the Coomassie blue-stained SDS-PAGE gel is shown in the right panel. Lane 1, molecular weight marker. Lane 2, purified receptor variant. Arrows indicate the purified receptors.

good FSEC pattern could be a sign of functional expression. Therefore, this platform for engineering stabilized variants could also be applicable to orphan GPCRs, for which functional assays such as ligand-binding assay would be difficult.

Higher expression of the variants than that of the fulllength receptors achieved in $S$. cerevisiae was also observed in $P$. pastoris for hADRB2, hCHRM2, hHRH1 and hNTSR1. We confirmed that improvements of GPCR variants were also observed in insect cells. The best host to yield a high quality and quantity of GPCR may depend on the GPCR type. It has been reported that the thermally stabilized NTSR1 variants selected in $E$. coli were also expressed at higher levels in $P$. pastoris and mammalian cells [17]. Therefore, the combination of E. coli or S. cerevisiae for rapid screening and $P$. pastoris for a large scale of expression could be a dominant strategy for the structural study of GPCR and other membrane proteins.

The purified hHRH1 variants expressed in S. cerevisiae and $P$. pastoris showed a high degree of monodispersity analyzed by SEC. The recent structural determinations of hHRH1 and hADORA2a were achieved by using $P$. pastoris expression system [40, 41]. These facts strongly suggest the potential of yeast as an expression host, which provide high quality receptor protein enough for crystallography. Nuclear magnetic resonance (NMR) spectroscopy is a promising tool to know the ligand binding to extracellular surface of GPCRs, which is unclear in crystal structure in many cases [51]. Yeast has been used for producing a large amount of isotope-labeled recombinant protein. Our platform can also be a useful system for NMR analysis.

\section{Conclusions}

We demonstrated that the GFP-based S. cerevisiae system served as an easy-to-handle and rapid platform for the construction and evaluation of GPCR variants. This platform should be a cost-effective and powerful tool for the extensive screening to identify a highly expressed and stable variant for crystallography. Higher expression of variant achieved in S. cerevisiae should be also achieved in other hosts. The combination of $S$. cerevisiae for rapid screening and $P$. pastoris for high expression could be an effective strategy for the structural study of GPCR.

\section{Methods}

\section{S. cerevisiae transformation and small-scale overexpression}

The transformation and overexpression in S. cerevisiae were basically performed according to the previous method [25]. We here used the $2-\mu$ vector pDDGFP-2 [24] and the vacuolar protease-deficient $S$. cerevisiae

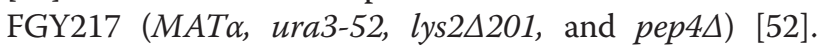
DNA fragments encoding the target GPCRs were amplified with the KOD Plus DNA polymerase (TOYOBO, Tokyo, Japan), with forward and reverse primers containing a $20-30$ bp gene-specific region and a $30 \mathrm{bp}$ homologous region [25]. Approximately $30 \mathrm{ng}$ of pDDGFP-2 and $3 \mu \mathrm{L}$ of $1 \sim 4$ PCR fragments of a GPCR (which have a $\sim 30 \mathrm{bp}$ overlapping region with each other) were transformed. Transformants were selected on Ura- plates at $30{ }^{\circ} \mathrm{C}$.

Colonies of transformants harboring the target GPCR were grown in $5 \mathrm{~mL}$ of Ura- medium with $2 \%$ glucose in $50 \mathrm{~mL}$ aerated capped tubes (TPP, Switzerland) at $30{ }^{\circ} \mathrm{C}$ overnight. The cultures were diluted to an $\mathrm{OD}_{600}$ of 0.12 and cultured in $10 \mathrm{~mL}$ of Ura- medium with $0.1 \%$ glucose at $30{ }^{\circ} \mathrm{C}$. At an $\mathrm{OD}_{600}$ of 0.6 , galactose was added to the culture to a final concentration of $2 \%$, DMSO was added as needed, and the temperature was lowered to $20{ }^{\circ} \mathrm{C}$ as needed. After shaking for $20-22 \mathrm{~h}$ at $30{ }^{\circ} \mathrm{C}$ (or $40 \mathrm{~h}$ at $20^{\circ} \mathrm{C}$ ), the cells were harvested, and the cell pellets were resuspended in $700 \mu \mathrm{L}$ of buffer A $(50 \mathrm{mM}$ Tris- $\mathrm{HCl}, \mathrm{pH}$ 7.5, $5 \mathrm{mM}$ EDTA, 10\% glycerol, $0.12 \mathrm{M}$ sorbitol, and complete protease inhibitor cocktail [Roche]). The cell suspensions were diluted 20-fold in buffer A, and whole-cell GFP fluorescence was measured with a SpectraMax M2e microplate reader (Molecular 
Devices, USA) in a 96-well black plate. Fluorescence at an emission wavelength of $525 \mathrm{~nm}$ was measured by using a $515 \mathrm{~nm}$ cutoff filter after excitation at $490 \mathrm{~nm}$. Purified yEGFP was used as a standard for estimating overexpression.

Membranes from small-scale $(10 \mathrm{~mL})$ cultures were prepared as follows. A yeast cell suspension $(700 \mu \mathrm{L})$ was transferred to $2 \mathrm{~mL}$ tubes containing $500 \mu \mathrm{L}$ of acidwashed, dry, 425 to $600 \mu \mathrm{m}$ glass beads (Sigma). Cells were disrupted on a Cutemixer CM-1000 (EYELA, Tokyo, Japan) at 2,500 rpm for $40 \mathrm{~min}$ at $4{ }^{\circ} \mathrm{C}$. The samples were examined microscopically to confirm that $>90 \%$ of the cells were broken. Unbroken cells and debris were pelleted by centrifugation, and the supernatant was transferred into an ultra-centrifuge tube. Yeast membranes were collected by ultracentrifugation at $100,000 \mathrm{~g}$ for $30 \mathrm{~min}$ at $4^{\circ}$ C. Prepared membranes were snap-frozen in liquid nitrogen and stored at $-80{ }^{\circ} \mathrm{C}$, or stored on ice and used within $24 \mathrm{~h}$.

\section{Intermediate and large-scale overexpression and membrane preparation in S. cerevisiae}

Yeast clones harboring the target receptor were inoculated in Ura- medium with $2 \%$ glucose and grown at $30{ }^{\circ} \mathrm{C}$ overnight. The yeast culture was diluted to an $\mathrm{OD}_{600}$ of 0.12 in a total volume of $200 \mathrm{~mL}$ or more than $1 \mathrm{~L}$ of Ura- medium with $0.1 \%$ glucose in a $500 \mathrm{~mL}$ baffle flask or $2.5 \mathrm{~L}$ Tunair flask (Sigma-Aldrich, USA), respectively. The culture was shaken at $250 \mathrm{rpm}$ at $30{ }^{\circ} \mathrm{C}$, and expression was induced by adding galactose to a final concentration of $2 \%$ when the culture reached an $\mathrm{OD}_{600}$ of 0.6 . After induction, the flasks were shaken for $20 \mathrm{~h}\left(30{ }^{\circ} \mathrm{C}\right.$ cultures $)$ or $40 \mathrm{~h}\left(20{ }^{\circ} \mathrm{C}\right.$ cultures), and the cells were harvested. Cells were washed once with lysis buffer (50 mM Tris-HCl, pH 7.5, $100 \mathrm{mM}$ $\mathrm{NaCl}, 5 \%$ glycerol, complete protease inhibitor cocktail, and $2 \mathrm{mM}$ EDTA), snap-frozen in liquid nitrogen, and stored at $-80{ }^{\circ} \mathrm{C}$.

The intermediate-scale cells were resuspended in the lysis buffer and disrupted in a $50 \mathrm{~mL}$ tube using an equal volume of glass beads on a Cutemixer at 2,500 rpm for $40 \mathrm{~min}$ at $4{ }^{\circ} \mathrm{C}$. The large-scale cells were disrupted in a $2 \mathrm{~L}$ baffled flask using an equal volume of glass beads on an Innova 44R shaker (New Brunswick Scientific Inc., USA) for $60 \mathrm{~min}$ at $4{ }^{\circ} \mathrm{C}$. Unbroken cells and debris were removed by centrifugation, the supernatant was transferred to ultracentrifuge tubes, and the membranes were pelleted by centrifugation at $100,000 \mathrm{~g}$ for $60 \mathrm{~min}$ at $4^{\circ}$ C. The pellet was suspended in buffer containing $50 \mathrm{mM}$ Tris- $\mathrm{HCl}, \mathrm{pH}$ 8.0, $120 \mathrm{mM} \mathrm{NaCl}, 20 \%$ glycerol and protease inhibitor cocktail, and stored at $-80{ }^{\circ} \mathrm{C}$.

\section{Radioligand-binding assays}

Membranes containing each GPCR-GFP were uniformly resuspended by sonication in individual assay buffers (Additional file 1: Table S2). Membrane proteins were quantified with the bicinchoninic acid (BCA) assay method (Pierce, USA). Membrane suspensions $(5-20 \mu \mathrm{g})$ were incubated in triplicate with specific radioactively-labeled ligands (Additional file 1: Table S2) for $1 \mathrm{~h}$ at $25{ }^{\circ} \mathrm{C}$. Nonspecific binding was determined in the presence of excess unlabeled ligand. Membranes were trapped on Whatman GF/B filters that were presoaked in $0.3 \%$ polyethylenimine. The bound and free radioligands were separated by washing three times with water. The retained radioactivity was measured on an LCS-5100 liquid scintillation counter (ALOKA).

\section{Fluorescence size exclusion chromatography (FSEC)}

Membrane suspensions of GPCRs were solubilized in buffer containing $50 \mathrm{mM}$ Tris- $\mathrm{HCl}, \mathrm{pH}$ 7.5, $200 \mathrm{mM} \mathrm{NaCl}$, protease inhibitor, and $1 \%$ detergent at a final concentration of $3 \mathrm{mg} / \mathrm{mL}$ total protein at $4{ }^{\circ} \mathrm{C}$ for $1 \mathrm{~h}$ with mild agitation. Insoluble material was pelleted by ultracentrifugation at $100,000 \mathrm{~g}$ at $4{ }^{\circ} \mathrm{C}$ for $30 \mathrm{~min}$. FSEC was performed with a Superose 6 10/300 column (GE Healthcare) on a Biologic Chromatography System (BioRad) with $500 \mu \mathrm{L}$ of solubilized sample. The column was preequilibrated with running buffer (20 mM Tris-HCl, pH 7.5, $150 \mathrm{mM} \mathrm{NaCl,} \mathrm{0.05 \%}$ DDM/0.01\% CHS). Fractions $(0.2 \mathrm{~mL})$ were collected in a 96-well microplate from the first $6 \mathrm{~mL}$ eluted after sample injection. Fluorescence emission at $525 \mathrm{~nm}$ was measured using a SpectraMax M2e plate reader with a $515 \mathrm{~nm}$ cutoff filter after excitation at $490 \mathrm{~nm}$.

\section{Overexpression in $P$. pastoris}

Using the GPCR-integrated pDDGFP-2 plasmids as templates, coding regions of the GPCR-GFP fusion proteins were PCR-amplified with a forward primer containing a BamHI site (5'-CTA GAA CTA GTG GAT CCA CCA TG-3') and a reverse primer containing an EcoRI site (5' GCT TGA TAT CGA ATT CCT GCA GTT AAT G-3'). The PCR products were digested with $\mathrm{BamHI}$ and EcoRI and subcloned into the pPIC9K vector. The vector was linearized using PmeI. Transformation, clone selection, and small-scale culturing were performed as previously described [53]. The selected transformants were stored in glycerol stocks at $-80{ }^{\circ} \mathrm{C}$. Intermediate-scale $(200 \mathrm{~mL})$ and large-scale (more than $1 \mathrm{~L}$ ) culturing were performed under the same conditions as small-scale culturing, with a $500 \mathrm{~mL}$ baffled flask and 2.5 L Tuniar Flask (Sigma-Aldrich, USA). $P$. pastoris cells from small- and intermediate-scale cultures were disrupted with glass beads and membranes were prepared in the same way as for S. cerevisiae.

\section{Purification of GPCR variants}

Purification of hHRH1-Nd-i3d expressed in P. pastoris and hHRH1-Nd-T4L expressed in S. cerevisiae was performed according to our previous report [41]. In brief, the 
membrane containing GPCR-GFP was solubilized by $1 \%$ $(\mathrm{w} / \mathrm{v}) \mathrm{DDM} / 0.2 \%(\mathrm{w} / \mathrm{v}) \mathrm{CHS}$, and the unsolubilized material was separated by ultracentrifugation. The GPCR-GFP fusion protein was purified with TALON IMAC resin (Clontech). The purified protein was concentrated, and then the protein was treated overnight with His-tagged TEV protease (expressed and purified in house). TEV protease and the cleaved His-tagged GFP were removed from the sample by passing the sample through TALON resin and collecting the flow through. All the purification steps were performed in the presence of $100 \mu \mathrm{M}$ pyrilamine.

\section{Additional file}

Additional file 1: Supplementary information. Table S1 Primers used for the construction of hHRH1 variant (Nd-F116W-T4L). Table S2 Ligands and conditions for the single point radioligand binding assays. Figure S1 In-gel fluorescence of 25 GPCR-GFP fusions expressed in S. cerevisiae Arrowheads represent the GPCR-GFP fusion bands and the asterisk represents an endogenous fluorescent 'background' protein from S. cerevisiae that migrates at approximately $70 \mathrm{kDa}$. Figure S2 Construction design of GPCR variants. (A) Sequence alignments of transmembrane 3 (TM3) of the GPCRs in this study with bovine rhodopsin and human ADORA2A. The number above the sequence is the general indexed position based on the Ballesteros-Weinstein system. The 3.41 position for receptor stabilization is highlighted in yellow. (B) Sequence alignments of TM5, i3-loop, and TM6. The position where the T4 lysozyme sequence is fused is shown in red. To truncate the long i3 loop, the residues shown in blue were connected for each receptor. Figure S3 Fluorescence intensity and activity of GPCR variants screened in S. cerevisiae. Whole-cell GFP fluorescence (arbitrary unit, bar graph) and specific activity of the membrane by radioligand binding assays (black square plot) of fulllength GPCRs and GPCR variants constructed in S. cerevisiae. (A) hADRB2, (B) hCHRM2, (C) hHRH1, and (D) hNTSR1. Figure S4 Evaluation of the GPCR variants expressed in Sf9 insect cells. The specific binding activities (left) and FSEC profiles (right) of full-length GPCRs and the improved GPCR variants expressed in Sf9 cells are shown. The colors of the chromatogram correspond to those in the binding assays. (A) hADRB2, (B) hCHRM2, (C) hHRH1, (D) hNTSR1. FSEC was performed with a Superose 6 10/300 column. The void peak is denoted by an asterisk. The arrow indicates the target peak of GPCR fused to GFP.

\section{Abbreviations}

GPCR: G-protein coupled receptor; GFP: Green fluorescent protein; FSEC: Fluorescence size exclusion chromatography; DDM: n-dodecyl- $\beta$-Dmaltopyranoside; CHS: Cholesteryl hemisuccinate; T4L: T4 lysozyme; TM: Transmembrane.

\section{Competing interests}

The authors declare that they have no competing interests.

\section{Authors' contributions}

MS, SI and TK designed the original research project. MS performed the screening of GPCRs using S. cerevisiae, the expression in P. pastoris and insect cells, the purification of the GPCR vatiants, and wrote the manuscript. HT and HM performed the screening of GPCRs using S. cerevisiae and ligand binding assay. HA carried out the Sf9 expression. TY-K carried out the P. pastoris expression. TS crystallized the HRH1 variant. TM and NN contributed to the data analysis and interpretation. TH constructed the CHRM2 gene. TK reviewed and wrote the manuscript. MS, SI and TK were responsible for overall project management. All authors provide editorial input.

\section{Acknowledgements}

We thank Dr. David Drew for providing materials and for helpful advice on the GFP-based system in S. cerevisiae. Ligand-binding assays were performed with the help of the radioisotope center at Kyoto University. This work was supported in part by a grant from the ERATO Iwata Human Receptor Crystallography Project from the Japan Science and Technology Agency (JST) (to S.I.), a Grant-in-Aid for Young Scientists (B) 23770123 (to M.S), a Grant-inAid for Scientific Research (B) (20370035 to T.K., 21370043 to T.S), Challenging Exploratory Research (22659059 to T.K.), Toray Science Foundation (to T.K.), Ichiro Kanehara Foundation (to T.K.), the Sumitomo Foundation (to T.K.), the Mochida Memorial Foundation for Medical and Pharmaceutical Research (to M.S. and T.K.), Takeda Science Foundation (to M.S. and T.K.), Kanae Foundation for the Promotion of Medical Science (to M.S.), and a Research Grant from CREST from Japan Science and Technology (to T.K.).

\section{Author details}

${ }^{1}$ Iwata Human Receptor Crystallography project, ERATO, JST,

Yoshidakonoe-choSakyo-ku, Kyoto 606-8501, Japan. ${ }^{2}$ Graduate School of Pharmaceutical Sciences, Kyushu University, 3-1-1 Maidashi, Higashi-ku, Fukuoka 812-8582, Japan. ${ }^{3}$ Department of Medical Chemistry and Cell Biology, Kyoto University Faculty of Medicine, Yoshidakonoe-choSakyo-ku, Kyoto 606-8501, Japan. ${ }^{4}$ Institute for Biomolecular Science, Faculty of Science, Gakushuin University, 1-5-1 MejiroToshima-ku, Tokyo 171-8588, Japan. ${ }^{5}$ Membrane Protein Crystallography Group, Division of Molecular Biosciences, Imperial College London, London SW7 2AZ, UK. ${ }^{6} J a p a n$ Science and Technology Agency, Core Research for Evolution Science and Technology (CREST), Kyoto University Faculty of Medicine, Kyoto 606-8501, Japan.

Received: 24 February 2012 Accepted: 20 May 2012

Published: 13 June 2012

\section{References}

1. Overington JP, Al-Lazikani B, Hopkins AL: How many drug targets are there? Nat Rev Drug Discov 2006, 5(12):993-996.

2. Palczewski K, Kumasaka T, Hori T, Behnke CA, Motoshima H, Fox BA, Le Trong Teller DC, Okada T, Stenkamp RE, et al: Crystal structure of rhodopsin: a G protein-coupled receptor. Science 2000, 289(5480):739-745.

3. Shimamura T, Hiraki K, Takahashi N, Hori T, Ago H, Masuda K, Takio K, Ishiguro M, Miyano M: Crystal structure of squid rhodopsin with intracellularly extended cytoplasmic region. J Bio/ Chem 2008, 283(26):17753-17756.

4. Murakami M, Kouyama T: Crystal structure of squid rhodopsin. Nature 2008, 453(7193):363-367.

5. Sarramegna V, Muller I, Milon A, Talmont F: Recombinant G protein-coupled receptors from expression to renaturation: a challenge towards structure. Cell Mol Life Sci 2006, 63(10):1149-1164.

6. McCusker EC, Bane SE, O'Malley MA, Robinson AS: Heterologous GPCR expression: a bottleneck to obtaining crystal structures. Biotechnol Prog 2007, 23(3):540-547.

7. Rasmussen SG, Choi HJ, Rosenbaum DM, Kobilka TS, Thian FS, Edwards PC, Burghammer M, Ratnala VR, Sanishvili R, Fischetti RF, et al: Crystal structure of the human beta2 adrenergic G-protein-coupled receptor. Nature 2007, 450 (7168):383-387.

8. Rosenbaum DM, Cherezov V, Hanson MA, Rasmussen SG, Thian FS, Kobilka TS, Choi HJ, Yao XJ, Weis WI, Stevens RC, et al: GPCR engineering yields highresolution structural insights into beta2-adrenergic receptor function. Science 2007, 318(5854):1266-1273.

9. Cherezov V, Rosenbaum DM, Hanson MA, Rasmussen SG, Thian FS, Kobilka TS, Choi HJ, Kuhn P, Weis WI, Kobilka BK, et al: High-resolution crystal structure of an engineered human beta2-adrenergic G protein-coupled receptor. Science 2007, 318(5854):1258-1265.

10. Warne T, Serrano-Vega MJ, Baker JG, Moukhametzianov R, Edwards PC, Henderson R, Leslie AG, Tate CG, Schertler GF: Structure of a beta(1)-adrenergic G-protein-coupled receptor. Nature 2008, 454(7203):486-491.

11. Jaakola VP, Griffith MT, Hanson MA, Cherezov V, Chien EY, Lane JR, ljzerman AP, Stevens RC: The 2.6 angstrom crystal structure of a human A2A adenosine receptor bound to an antagonist. Science 2008, 322(5905):1211-1217.

12. Chien EY, Liu W, Zhao Q, Katritch V, Han GW, Hanson MA, Shi L, Newman AH, Javitch JA, Cherezov V, et al: Structure of the human dopamine D3 receptor in complex with a D2/D3 selective antagonist. Science 2010, 330(6007):1091-1095.

13. Wu B, Chien EY, Mol CD, Fenalti G, Liu W, Katritch V, Abagyan R, Brooun A, Wells P, Bi FC, et al: Structures of the CXCR4 chemokine GPCR with small-molecule and cyclic peptide antagonists. Science 2010, 330(6007):1066-1071. 
14. Serrano-Vega MJ, Magnani F, Shibata Y, Tate CG: Conformational thermostabilization of the beta1-adrenergic receptor in a detergent-resistant form. Proc Natl Acad Sci U S A 2008, 105(3):877-882

15. Magnani F, Shibata Y, Serrano-Vega MJ, Tate CG: Co-evolving stability and conformational homogeneity of the human adenosine A2a receptor. Proc Natl Acad Sci U S A 2008, 105(31):10744-10749.

16. Lebon G, Bennett K, Jazayeri A, Tate CG: Thermostabilisation of an agonistbound conformation of the human adenosine $\mathrm{A}(2 \mathrm{~A})$ receptor. $J \mathrm{Mol} \mathrm{BiO}$ 2011, 409(3):298-310.

17. Sarkar CA, Dodevski I, Kenig M, Dudli S, Mohr A, Hermans E, Pluckthun A: Directed evolution of a $\mathrm{G}$ protein-coupled receptor for expression, stability, and binding selectivity. Proc Natl Acad Sci U S A 2008, 105(39):14808-14813.

18. Warne T, Serrano-Vega MJ, Baker JG, Moukhametzianov R, Edwards PC, Henderson R, Leslie AG, Tate CG, Schertler GF: Structure of a beta1adrenergic G-protein-coupled receptor. Nature 2008, 454(7203):486-491.

19. Lebon G, Warne T, Edwards PC, Bennett K, Langmead CJ, Leslie AG, Tate CG: Agonist-bound adenosine A2A receptor structures reveal common features of GPCR activation. Nature 2011, 474(7352):521-525.

20. Sarramegna $V$, Talmont F, Demange $P$, Milon A: Heterologous expression of $\mathrm{G}$-protein-coupled receptors: comparison of expression systems fron the standpoint of large-scale production and purification. Cell Mol Life Sci 2003, 60(8):1529-1546.

21. Lundstrom K, Wagner R, Reinhart C, Desmyter A, Cherouati N, Magnin T, Zeder-Lutz G, Courtot M, Prual C, Andre N, et al: Structural genomics on membrane proteins: comparison of more than 100 GPCRs in 3 expression systems. J Struct Funct Genom 2006, 7(2):77-91.

22. Beukers MW, ljzerman AP: Techniques: how to boost GPCR mutagenesis studies using yeast. Trends Pharmacol Sci 2005, 26(10):533-539.

23. Junge F, Schneider B, Reckel S, Schwarz D, Dotsch V, Bernhard F: Large-scale production of functional membrane proteins. Cell Mol Life Sci 2008 , 65(11):1729-1755.

24. Newstead S, Kim H, von Heijne G, Iwata S, Drew D: High-throughput fluorescent-based optimization of eukaryotic membrane protein overexpression and purification in Saccharomyces cerevisiae. Proc Natl Acad Sci U S A 2007, 104(35):13936-13941.

25. Drew D, Newstead S, Sonoda Y, Kim H, von Heijne G, Iwata S: GFP-based optimization scheme for the overexpression and purification of eukaryotic membrane proteins in Saccharomyces cerevisiae. Nat Protoc 2008, 3(5):784-798

26. Kawate T, Gouaux E: Fluorescence-detection size-exclusion chromatography for precrystallization screening of integral membrane proteins. Structure 2006, 14(4):673-681.

27. Ito K, Sugawara T, Shiroishi M, Tokuda N, Kurokawa A, Misaka T, Makyio H, Yurugi-Kobayashi T, Shimamura T, Nomura N, et al: Advanced method for high-throughput expression of mutated eukaryotic membrane proteins in Saccharomyces cerevisiae. Biochem Biophys Res Commun 2008, 371(4):841-845

28. Drew D, Lerch M, Kunji E, Slotboom DJ, de Gier JW: Optimization of membrane protein overexpression and purification using GFP fusions. Nat Methods 2006, 3(4):303-313.

29. Weiss HM, Haase W, Michel H, Reilander H: Expression of functional mouse 5HT5A serotonin receptor in the methylotrophic yeast Pichia pastoris: pharmacological characterization and localization. FEBS Lett 1995, 377(3):451-456.

30. Talmont F, Sidobre S, Demange P, Milon A, Emorine L: Expression and pharmacological characterization of the human mu-opioid receptor in the methylotrophic yeast Pichia pastoris. FEBS Lett 1996, 394(3):268-272.

31. Andersen B, Stevens RC: The human D1A dopamine receptor: heterologous expression in Saccharomyces cerevisiae and purification of the functional receptor. Protein Expr Purif 1998, 13(1):111-119.

32. Grunewald S, Haase W, Molsberger E, Michel H, Reilander H: Production of the human D2S receptor in the methylotrophic yeast $P$. pastoris. Receptors Channels 2004, 10(1):37-50.

33. Andre N, Cherouati N, Prual C, Steffan T, Zeder-Lutz G, Magnin T, Pattus F, Michel $H$, Wagner R, Reinhart C: Enhancing functional production of $G$ protein-coupled receptors in Pichia pastoris to levels required for structural studies via a single expression screen. Protein Sci 2006, 15(5):1115-1126

34. Hanson MA, Cherezov V, Griffith MT, Roth CB, Jaakola VP, Chien EY, Velasquez J, Kuhn P, Stevens RC: A specific cholesterol binding site is established by the $2.8 \mathrm{~A}$ structure of the human beta2-adrenergic receptor. Structure 2008, 16(6):897-905.

35. Warne T, Chirnside J, Schertler GF: Expression and purification of truncated, non-glycosylated turkey beta-adrenergic receptors for crystallization. Biochim Biophys Acta 2003, 1610(1):133-140.

36. Ballesteros JA, Weinstein $\mathrm{H}$ : Integrated methods for the construction of three dimentional models and computational probing of structure-function relations in G-protein coupled receptors. Methods Neurosci 1995, 25:366-428.

37. Roth CB, Hanson MA, Stevens RC: Stabilization of the human beta2-adrenergic receptor TM4-TM3-TM5 helix interface by mutagenesis of Glu122(3.41), a critical residue in GPCR structure. J Mol Biol 2008, 376(5):1305-1319.

38. Hayashi MK, Haga T: Purification and functional reconstitution with GTP-binding regulatory proteins of hexahistidine-tagged muscarinic acetylcholine receptors (m2 subtype). J Biochem 1996, 120(6):1232-1238.

39. Erlenbach I, Kostenis E, Schmidt C, Hamdan FF, Pausch MH, Wess J: Functional expression of $M(1), M(3)$ and $M(5)$ muscarinic acetylcholine receptors in yeast. J Neurochem 2001, 77(5):1327-1337.

40. Hino T, Arakawa T, Iwanari H, Yurugi-Kobayashi T, Ikeda-Suno C, Nakada-Nakura Y, Kusano-Arai O, Weyand S, Shimamura T, Nomura N, et al: G-protein-coupled receptor inactivation by an allosteric inverse-agonist antibody. Nature 2012, 482(7384):237-240.

41. Shimamura T, Shiroishi M, Weyand S, Tsujimoto H, Winter G, Katritch V, Abagyan R, Cherezov V, Liu W, Han GW, et al: Structure of the human histamine H1 receptor complex with doxepin. Nature 2011, 475(7354):65-70.

42. Fraser NJ: Expression and functional purification of a glycosylation deficient version of the human adenosine 2a receptor for structural studies. Protein Expr Purif 2006, 49(1):129-137.

43. Noguchi S, Satow Y: Purification of human beta2-adrenergic receptor expressed in methylotrophic yeast Pichia pastoris. J Biochem 2006, 140(6):799-804.

44. Hori T, Sato Y, Takahashi N, Takio K, Yokomizo T, Nakamura M, Shimizu T, Miyano M: Expression, purification and characterization of leukotriene B (4) receptor, BLT1 in Pichia pastoris. Protein Expr Purif 2010, 72(1):66-74.

45. Asada H, Uemura T, Yurugi-Kobayashi T, Shiroishi M, Shimamura T, Tsujimoto H, Ito K, Sugawara T, Nakane T, Nomura N, et al: Evaluation of the Pichia pastoris expression system for the production of GPCRs for structural analysis. Microb Cell Fact 2011, 10:24.

46. Singh S, Gras A, Fiez-Vandal C, Ruprecht J, Rana R, Martinez M, Strange PG, Wagner R, Byrne B: Large-scale functional expression of WT and truncated human adenosine A2A receptor in Pichia pastoris bioreactor cultures. Microb Cell Fact 2008, 7:28

47. Shiroishi M, Kobayashi T, Ogasawara S, Tsujimoto H, Ikeda-Suno C, Iwata S, Shimamura T: Production of the stable human histamine $\mathrm{H}(1)$ receptor in Pichia pastoris for structural determination. Methods 2011, 55(4):281-286.

48. Fredriksson R, Lagerstrom MC, Lundin LG, Schioth HB: The G-protein-coupled receptors in the human genome form five main families. Phylogenetic analysis, paralogon groups, and fingerprints. Mol Pharmacol 2003, 63 (6):1256-1272

49. Lagerstrom MC, Schioth HB: Structural diversity of G protein-coupled receptors and significance for drug discovery. Nat Rev Drug Discov 2008, 7(4):339-357.

50. Shibata Y, White JF, Serrano-Vega MJ, Magnani F, Aloia AL, Grisshammer R, Tate CG: Thermostabilization of the neurotensin receptor NTS1. J Mol Biol 2009, 390(2):262-277.

51. Bokoch MP, Zou Y, Rasmussen SG, Liu CW, Nygaard R, Rosenbaum DM, Fung JJ, Choi HJ, Thian FS, Kobilka TS, et al: Ligand-specific regulation of the extracellular surface of a G-protein-coupled receptor. Nature 2010, 463(7277):108-112

52. Kota J, Gilstring CF, Ljungdahl PO: Membrane chaperone Shr3 assists in folding amino acid permeases preventing precocious ERAD. J Cell Biol 2007, 176(5):617-628

53. Scorer CA, Clare JJ, McCombie WR, Romanos MA, Sreekrishna K: Rapid selection using G418 of high copy number transformants of Pichia pastoris for high-level foreign gene expression. Biotechnology (N Y) 1994 12(2):181-184

doi:10.1186/1475-2859-11-78

Cite this article as: Shiroishi et al:: Platform for the rapid construction and evaluation of GPCRs for crystallography in Saccharomyces cerevisiae. Microbial Cell Factories 2012 11:78 